University for Business and Technology in Kosovo

UBT Knowledge Center

UBT International Conference

2016 UBT International Conference

Oct 28th, 9:00 AM - Oct 30th, 5:00 PM

\title{
Tax Evasion as a Crime: A Survey of Perception in Kosovo
}

Agim Mamuti

University of New York in Tirana, agim.mamuti@yahoo.com

Robert McGee

Fayetteville State University, bob414@hotmail.com

Follow this and additional works at: https://knowledgecenter.ubt-uni.net/conference

Part of the Business Commons

\section{Recommended Citation}

Mamuti, Agim and McGee, Robert, "Tax Evasion as a Crime: A Survey of Perception in Kosovo" (2016). UBT International Conference. 18.

https://knowledgecenter.ubt-uni.net/conference/2016/all-events/18

This Event is brought to you for free and open access by the Publication and Journals at UBT Knowledge Center. It has been accepted for inclusion in UBT International Conference by an authorized administrator of UBT Knowledge Center. For more information, please contact knowledge.center@ubt-uni.net. 


\title{
Tax Evasion as a Crime: A Survey of Perception in Kosovo
}

\author{
Agim Mamuti ${ }^{1}$, Robert McGee ${ }^{2}$ \\ ${ }^{1}$ Faculty of Business and Economics, University of New York in Tirana, \\ ${ }^{2}$ Department of Accounting, Fayetteville State University, \\ agim.mamuti@yahoo.com, bob414@hotmail.com
}

\begin{abstract}
The goal of this paper is to explore the perception of Kosovo's citizens of the severity of tax evasion relative to other crimes and abuses. Perception of tax evasion may somewhat clarify the degree of rebelliousness with the tax laws. Using data from a self- administered survey and a personnel structured interview, the results of mean and comparative analysis will be examined to show where the tax evasion is ranked in Kosovo in the list of fifty listed crimes.

Studies, conducted about the perceptions of tax evasion as a crime, have suggested that the tax non-compliance environment has been created from the perception of the taxpayers towards tax evasion as a non-serious crime. Consequently, the degree of non-compliance with the tax laws could be explained somewhat by the perception towards the tax evasion. And, it is obvious that the public's perception of the severity of a crime has important implications for society. [1] However, those studies are inconclusive in explaining the variability of the perceptions towards tax evasion as a crime. Despite that fact that these researches conducted on this area in US, Australia, and Malaysia are a few, a study about the perception of tax evasion in Kosovo does not exist. Evidence on tax evasion perception found in the developing countries may not be generalized to the context of Kosovo because of the differences in the environmental factors such as economy, business, culture, and regulations. Consequently, differences in the environmental factors are expected to cause differences in the perception.

The results of this study should be useful to business and government representatives in Kosovo and elsewhere in the Balkans or wider.
\end{abstract}

Keywords: tax evasion, tax ethics, crimes, Kosovo

\section{Introduction}

It is no doubt that, in every country tax evasion has weakened the government's tax and lowered the ability of government to provide public goods. Additionally, the tax evasion also causes some other problems being adverse to the economic development. For example, the tax evasion distorts the tax system, increasing the deadweight loss. While increasing the government's law enforcement costs, it also reduces the government tax revenue and the ability to repay. Therefore, to examine the perception of tax evasion as a crime is very important for us.

\subsection{Literature Review}

Although many studies regarding tax evasion have been made worldwide, there are just a few studies made of Kosovo as a case study. Abdixhiku, L., in his doctoral dissertation defines tax evasion as one of the major problems facing transition and developing economies. According to him, it imposes several economic costs: it slows down economic growth; it diverts resources to 
unproductive activities; it provides an incentive for firms to remain small and invisible; and it generates inequity between the evaders and the honest taxpayers. The aim of his thesis has been to investigate the determinants of business tax evasion for transition economies. He has adapted the individual theory to the case of businesses; that is by assuming that the behavior of businesses is similar to the behavior of individuals, and that the determinants of business tax evasion may be similar, at least qualitatively, to the determinants of tax evasion by individuals or households. More specifically, beyond theoretical and empirical review of the tax evasion literature, this thesis provides three related empirical investigations: a panel investigation of tax evasion at the country level; a pooled-cross section investigation of firm-level behavior across the transition economies and a cross-section investigation of business tax evasion and tax morale in Kosovo. [2]

Tax compliance is mainly seen from a financial and economic point of view, rather than a psychological or philosophical point of view. One of the most important and rare documents regarding the ethics of tax evasion was a doctoral thesis written by Martin Crowe (1944). This thesis covered the moral point of view of paying taxes to the government. This paper is mostly focused on Crowe's writing and on Robert McGee's articles related to the perception of tax evasion as a crime, conducted in different countries. [3]

Tax evasion is inevitable. Only most fanciful thoughts can dream of a world whose citizens inspired by altruism, pride or even religious passion and beliefs are willing to fully comply without the need for institutional enforcement. [4]

\section{Methodology and Results}

\subsection{Methodology}

This research tries to investigate the level of seriousness of tax evasion compared to other offences. A comparison will be made among the rank of each crime and violation given by the respondents as a high or low rank crime or violation. Further, the tax evasion crime rank will be identified among the list of the offences to determine the level of the seriousness of this crime compared to other offences.

The level of seriousness of tax evasion compared to other crimes and violation has been evidenced, previously, by a few studies. [1][5] The results indicated by those studies that there is a significant difference in the perceptions of tax evasion compared with violent crimes, drug related crimes and traffic offences. The results suggest that people do not perceive tax evasion to be as serious as violent crime and drug related crimes. Thus, the following hypothesis is developed to be tested by the current study:

H1: Tax evasion is perceived a less serious crime compared to other offences.

A sample of 365 individuals from Kosovo was selected for the current study to obtain data from using the disproportionate stratified random sampling. These individuals are the most suitable people to provide data about the dimensions of the study. Under simple random sampling, all elements in the population are considered and each element has an equal chance of being chosen as the subject. The sample subjects include individuals who are students, working for private and governmental sectors, businessmen, jobless and self-employed individuals. Two hundred sixtynine (269) questionnaires were returned, which represent a 76.85\% response rate. Forty percent of the sample was female and sixty percent male.

In this study, data are obtained from primary sources by conducting a survey. Using this method of data collection, individuals were asked to fill in the self administered questionnaire. This questionnaire is adopted and adapted from the previous studies conducted to measure the perceptions toward tax evasion as a crime by McGee, Robert. [3] A survey is chosen because it involves surveying people and recording their responses for analysis. The strength of the survey 
as a primary data collecting approach is that it does not require a visual or other objective perception of the information sought. [6]

\subsection{Results}

The questionnaire is divided into two sections. The first section of the questionnaire is designed to obtain demographic characteristics of the respondents, and the second section measured opinions on 50 different offences. The respondents are asked to indicate their agreement on all items by indicating numbers from 1 to 100 , representing the following levels:

1-20 Not Serious

21-40 Somewhat Serious

41-60 Serious

61-80 Very Serious

81-100 Extremely Serious.

As we already mentioned, the first part of the questionnaire is designed to obtain a demographic profile of the respondents. Questions asked in this part relate to age, gender, marital status, education, birthplace, and religion.

As shown in Table 1, the majority of the respondents (60\%) were male, and $40 \%$ were female. The largest group (68\%), in terms of age, was those aged between 18 and 29. Specifically, 17\% were aged between 30 and 49 , while $15 \%$ were aged above 50 . In terms of marital status, the majority of the respondents ( $80 \%$ ) were single, $19 \%$ was married, and $1 \%$ was either divorced or widowed. Regarding the level of education, the largest group (64\%) was undergraduate student or a bachelor degree holder, $23 \%$ was a graduate student or graduated, and $13 \%$ have other kind of education. The majority of respondents (76\%) were Muslim, $14 \%$ were Catholics, $4 \%$ were Orthodox and $6 \%$ have different beliefs. In terms of birthplace, $96 \%$ were born in Kosovo, and the rest somewhere else. 
Book of Proceedings International Conference on Management, Business and Economics

Table 1 Socio-demographic data of respondents

\begin{tabular}{|l|c|c|}
\hline Demographic Variables & Frequency $\mathbf{( n = 2 6 9 )}$ & Percent \\
\hline Gender & & 60 \\
\hline Male & 162 & 40 \\
\hline Female & 107 & 68 \\
\hline Age (years) & 183 & 17 \\
\hline $18-29$ & 47 & 15 \\
\hline $30-49$ & 39 & \\
\hline 50 and above & & 80 \\
\hline Marital Status & 214 & 19 \\
\hline Single & 52 & 1 \\
\hline Married & 3 & 64 \\
\hline Other & & 23 \\
\hline Education & 162 & 13 \\
\hline Undergraduate & 73 & \\
\hline Graduate & 34 & 11 \\
\hline Other & & 48 \\
\hline Major & 29 & 17 \\
\hline Accounting & 131 & 24 \\
\hline Business & 45 & \\
\hline Law & 64 & 96 \\
\hline Other & & 4 \\
\hline Born in & 258 & 14 \\
\hline Kosovo & 11 & 4 \\
\hline Elsewhere & 16 & \\
\hline Religion & 204 & \\
\hline Islam & 37 & \\
\hline Catholic & 11 & \\
\hline Orthodox & 1 & \\
\hline Agnostic/Atheist & & \\
\hline Other & & \\
\hline & & \\
\hline
\end{tabular}

The second section highlights perceived differences in perception of tax evasion offences compared to other offences. Table 2 highlights the Mean Scores and Rank of the 50 offences examined under this study.

As it is shown in Table 2 that the most five serious crimes are murdering someone, and drug trafficking/dealing. On the other side, the least serious offences are ranked as: Overstatement of tax deductions; Understatement of taxable income; Ticket scalping; Failing to report rental income; Cheating on your tax return. It is obvious that the three items related to tax evasion are ranked $46^{\text {th }}, 49^{\text {th }}$ and $50^{\text {th }}$ offences.

Importantly, the results of the previous studies ranked the first five offences to be murder, rape and child molestation, drug trafficking and robbery with firearms and the least serious crimes as failure to submit a tax return, driving while using mobile phone, speeding, overstatement of tax deductions and understatement of taxable income. [5] 
Tax Evasion as a Crime: A Survey of Perception in Kosovo

Table 2 Perceptions towards Tax Evasion Compared to Other Offences

\begin{tabular}{|c|c|c|}
\hline Description of Offense & Mean & Rank \\
\hline $\begin{array}{l}\text { Killing a nice person who has a family and who is a productive member of the } \\
\text { community }\end{array}$ & 99.21 & 1 \\
\hline $\begin{array}{l}\text { Killing someone who asked you to kill them because they have a terminal disease } \\
\text { and are in a lot of pain }\end{array}$ & 98.76 & 2 \\
\hline Killing a politician & 97.23 & 3 \\
\hline Killing a drug dealer & 96.03 & 4 \\
\hline Taking hard drugs & 94.02 & 5 \\
\hline Selling hard drugs & 92.33 & 6 \\
\hline Rape & 91.35 & 7 \\
\hline Soliciting a prostitute & 87.45 & 8 \\
\hline Sexually harassing someone & 85.64 & 9 \\
\hline Prostitution & 83.22 & 10 \\
\hline Smoking marijuana & 81.17 & 11 \\
\hline Selling marijuana & 80.05 & 12 \\
\hline Causing a hit-and-run accident & 78.77 & 13 \\
\hline Driving through a red light & 76.58 & 14 \\
\hline Driving without a license & 74.24 & 15 \\
\hline Driving while intoxicated & 72.04 & 16 \\
\hline Firing someone because of delivery and child care & 71.02 & 17 \\
\hline Paying less than the minimum wage & 69.87 & 18 \\
\hline Not hiring someone because of age & 67.22 & 19 \\
\hline Not hiring someone because of gender & 66.45 & 20 \\
\hline Bicycle theft & 65.78 & 21 \\
\hline Stealing $\$ 50$ from a friend & 65.38 & 22 \\
\hline Pocketing $\$ 50$ from the company which you work for & 64.87 & 23 \\
\hline Stealing $\$ 50$ from a stranger & 64.33 & 24 \\
\hline Shoplifting & 64.12 & 25 \\
\hline Robbery & 63.89 & 26 \\
\hline Avoiding a fare on a bus (that is owned by a private company) & 62.33 & 27 \\
\hline Avoiding a fare on a bus (that is owned by the local government) & 61.59 & 28 \\
\hline Helping a client cheat on taxes & 60.87 & 29 \\
\hline Faking one's academic record & 60.43 & 30 \\
\hline Claiming government benefits to which you are not entitled & 59.76 & 31 \\
\hline Speeding - driving over the speed limit & 58.45 & 32 \\
\hline Soliciting a bribe & 58.13 & 33 \\
\hline Cheating on an exam & 57.88 & 34 \\
\hline Accepting an unsolicited bribe & 56.65 & 35 \\
\hline Paying a bribe when pressured to do so & 56.32 & 36 \\
\hline Offering to pay a bribe & 55.23 & 37 \\
\hline Purchasing a term paper and submitting it as your own & 54.25 & 38 \\
\hline Sneaking into a movie without paying & 53.24 & 39 \\
\hline Buying a pirated CD/DVD & 52.64 & 40 \\
\hline Copying software illegally & 51.46 & 41 \\
\hline Paying cash to avoid paying sales tax [value added tax] & 50.74 & 42 \\
\hline Accounting fraud & 50.62 & 43 \\
\hline Insider stock trading & 49.28 & 44 \\
\hline
\end{tabular}


Book of Proceedings

International Conference on Management, Business and Economics

\begin{tabular}{|l|r|r|}
\hline Insurance fraud & 49.12 & 45 \\
\hline Cheating on your tax return & 48.35 & 46 \\
\hline Failing to report rental income & 47.54 & 47 \\
\hline Ticket scalping (purchasing a ticket to an event and reselling it at a higher price) & 46.48 & 48 \\
\hline Understatement of taxable income & 45.79 & 49 \\
\hline Overstatement of tax deductions & 45.12 & 50 \\
\hline
\end{tabular}

\section{CONCLUSIONS AND RECOMMENDATIONS}

\section{Conclusions}

The results of the performed analysis indicate that citizens of Kosovo perceive tax evasion as the least serious crime compared to the other 47 given offences and there is a difference between the category of tax evasion as a crime and the other categories of crimes in terms of their severity. The three tax evasion items were ranked $46^{\text {th }}, 49^{\text {th }}$ and $50^{\text {th }}$ offences out of 50 crimes and the tax evasion category was ranked as the least mean score. Accordingly, hypothesis $\mathrm{H} 1$, which is developed as tax evasion is perceived a less serious crime compared to other offences, is accepted.

The general trend of perceptions seems to be similar and consistent with the previous studies of Karlinsky et al. [1] and Abdual Manaf and Abdul Jabbar [5]. Kandri, E. and Mamuti, A., are considering that tax evasion is not a matter of state financial policies rather than a society's principles and morals. Nevertheless, it may never be addressed as an ethical deed rather than lack of will to contribute to the society you live in.[7]

\section{Limitations and Recommendations}

This study is still subject to some limitations. One of the limitations of this study is that this paper has reported 269 respondents' opinion towards tax evasion. Thus, the results have not shown a whole picture of all people in Kosovo. Future research is required to extend the results of this research and fill in this gap. The second limitation of this study is that the time considered under investigation is limited to the perception of people in 2016. Hence, future research is required to extend the results of this study by covering a range of previous years to this study and/or postperiods to this study. Finally, this study has explored the perception of people from Kosovo towards tax evasion using questionnaires. Therefore, the results found in this study are limited to the methodological approach used. Future research is required to extend and confirm these results by using different methodological approaches and introducing several variables such as the country-specific factors: culture, political system, economic development, etc.

\section{References}

1. Karlinsky, S., Burton, H., \& Blanthorne, C. (2004). Perceptions of Tax Evasion as a Crime. E-Journal of Tax Research, 2 (2), pp. 226-240.

2. Abdixhiku, L. (2013). "Determinants of Business Tax Evasion in Transition Economies", Doctoral Thesis, Staffordshire Business School. 
3. McGee, Robert et.al. (2014). "How Serious is Tax Evasion? An Empirical Legal Answer", The Indonesian Journal of International \& Comparative Law, pp.218-256.

4. Cowell, F. (1990). "Cheating the government: The economics of evasion", Cambridge, Mass. and London: MIT Press.

5. Abdul Manaf, N., \& Abdul Jabbar, H. (2006). A Survey of Perception towards Tax Evasion as a Crime.

6. Cohen, J. (1988). Statical Power Analysis for the Behavioral Science. Hillsdale, New Jersey: Lawrence Erlbaum.

7. Kandri, Emirjeta and Mamuti, Agim, The Ethics of Tax Evasion, Case of Albania, Book of Proceedings, UBT Conference 2015 